\title{
DMT1-Mutant Erythrocytes have Shortened Life Span, Accelerated Glycolysis and Increased Oxidative Stress
}

\author{
Zuzana Zidova Katarina Kapralova Pavla Koralkova Renata Mojzikova \\ Dalibor Dolezal Vladimir Divoky Monika Horvathova \\ Department of Biology, Faculty of Medicine and Dentistry Palacky University, Olomouc, Czech Republic
}

\section{Key Words}

DMT1 $・$ Eryptosis $・$ Oxidative stress

\begin{abstract}
Background/Aims: Deficiency of the divalent metal transporter 1 (DMT1) leads to hypochromic microcytic anemia. We have previously shown that DMT1 deficiency impairs erythroid differentiation and induces apoptosis of erythroid cells. Here we analyzed metabolic processes and survival of mature erythrocytes in order to address potential involvement of erythrocyte defect in the pathophysiology of the disease. Methods: FACS analysis was used to determine the half-life of erythrocytes (CFSE fluorescence), phosphatidylserine exposure (Annexin $\mathrm{V}$ binding), cytosolic $\mathrm{Ca}^{2+}$ (Fluo3/AM fluorescence) and reactive oxygen species (ROS; DCF fluorescence). Enzyme activities were determined by standard biochemical methods. The concentration of ATP and ADP was measured on HPLC-MS/MS. Results: We observed an accelerated clearance of CFSE-labeled DMT1-mutant erythrocytes from circulating blood when compared to wild-type erythrocytes. In vitro, DMT1-mutant erythrocytes showed significantly increased Annexin $\mathrm{V}$ binding after exposure to hyperosmotic shock and glucose depletion. Despite exaggerated anti-oxidative defense, higher ROS levels were present in DMT1-mutant erythrocytes. Accelerated anaerobic glycolysis and reduced ATP/ADP ratio detected in DMT1mutant erythrocytes indicate enhanced demand for ATP. Conclusions: We propose that DMT1 deficiency negatively affects metabolism and life span of mature erythrocytes; two other aspects of defective erythropoiesis which contribute to the pathophysiology of the disease.
\end{abstract}




\section{Introduction}

Divalent metal transporter 1 (DMT1; also known as NRAMP2 and SLC11A2) is an intestinal and endosomal iron $\left(\mathrm{Fe}^{2+}\right)$ transporter [1]. Mutations inactivating DMT1 are associated with a severe defect in erythroid iron utilization and cause moderate to severe hypochromic microcytic anemia in human patients [2-6] and two rodent models, $\mathrm{mk} / \mathrm{mk}$ mice [7] and Belgrade rats [8]. In addition, DMT1 knockout animals (Slc11a2-/-) die in the first week of life due to iron deficient erythropoiesis [1].

It has been shown that nutritional iron deficiency [9] and certain types of congenital hypochromic anemia such as thalassemia and sickle cell disease [10] are associated with shortened life span of erythrocytes. The accelerated clearance of erythrocytes can be attributed to excessive hemolysis and/or induction of programmed cell death of erythrocytes, called eryptosis [11]. This suicidal death of erythrocytes is characterized by cell shrinkage, cell membrane blebbing and cell membrane phospholipid scrambling. Eryptosis is triggered by oxidative stress, hyperosmotic shock and glucose depletion likely via activation of $\mathrm{Ca}^{2+}$ cation channels leading to an increase in the concentration of cytosolic $\mathrm{Ca}^{2+}[12,13]$.

We have previously shown that DMT1 deficiency leads to an impaired erythroid differentiation hallmarked by accumulation of immature forms of erythroblast, accelerated apoptosis of erythroid precursors and diminished survival of erythroid progenitors [14]. In the presented study we aimed to explore whether eryptosis contributes to the pathophysiology of anemia associated with mutations in DMT1.

\section{Materials and Methods}

Animals

Heterozygous mice bearing the G185R DMT1 mutation ( $m k /+$, strain 129S6/SvEvTac) [1] were provided by M. Fleming (Children's Hospital, Boston, USA). Mice were fed a standard diet; 10- to 16-week-old $\mathrm{mk} / \mathrm{mk}$ mice and their wild-type (wt) littermates were included in the study. Experiments were performed in accordance with the Palacky University Institutional Animal Care and Use Committee. Where indicated, erythrocytes from tail vein or heart puncture were depleted from reticulocytes on Percoll (GE Healthcare Life Sciences, United Kingdom, $\rho=1.130 \pm 0.005 \mathrm{~g} / \mathrm{ml}$ ) using density gradient centrifugation [15].

\section{Half-life of fluorescently labeled erythrocytes}

Erythrocytes of wt and DMT1-mutant mice were isolated from blood by low speed centrifugation followed by two washes with Ringer solution according to Qadri et al. [16]. Separated erythrocytes were stained in vitro with the carboxyfluorescein diacetate succinimidyl ester (CFSE; Molecular Probes, Invitrogen, CA, USA) as previously described [17]. The efficiency of CFSE-labeling ( $>99 \%$ ) was determined by flow cytometry (FACS Calibur, BD Biosciences, New Jersey, USA). Fluorescently labeled erythrocytes $\left(1 \times 10^{9}\right.$ in $100 \mu \mathrm{l}$ of PBS) were injected into the tail veins of wt mice. The intensity of erythrocyte fluorescence was measured using the tail vein blood taken on selected days following the injection. The percentage of CFSEpositive erythrocytes determined two hours post-injection was considered as $100 \%$.

\section{Assessment of hemolysis}

The in vitro hemolysis test was performed as previously described [18]. Erythrocytes $(0.4 \%$ hematocrit) were incubated at $37^{\circ} \mathrm{C}$ for 24 hours; thereafter the absorbance at $540 \mathrm{~nm}$ was read in the supernatant (spectrophotometer Infinite 200 Nanoquant; Tecan, Switzerland). In the cryohemolysis test, the erythrocytes were resuspended in pre-heated hypertonic sucrose solution $(700 \mathrm{mM}$ in $0.9 \% \mathrm{w} / \mathrm{v}$ sodium chloride solution, $\mathrm{pH} 7.4$ ), incubated $10 \mathrm{~min}$ at $37^{\circ} \mathrm{C}$ and transferred on ice [19]. After additional 10 min the absorbance at $540 \mathrm{~nm}$ was read in the supernatant. $100 \%$ hemolysate in both hemolysis tests was prepared by mixing the erythrocyte solution with distilled water. Bilirubin levels $[\mu \mathrm{M}]$ in the plasma were measured according to Cruickshank [20] and calculated using the formula: (absorbance at 453 - absorbance at 578) x dilution. 
Erythrocyte Annexin V binding in vitro

Percoll-separated erythrocytes were in vitro exposed to hyperosmotic shock (700 m0sm) and glucose depletion, respectively [9]. Annexin $V$ binding to erythrocytes was analyzed 5 and 7 hours later using Annexin V/FITC kit (BD Biosciences, New Jersey, USA). Fluorescence intensity was measured by FACS Calibur.

Determination of intracellular $\mathrm{Ca}^{2+}$

Erythrocytes separated on Percoll $\left(2 \times 10^{7} / \mathrm{ml}\right)$ were loaded with $2 \mu \mathrm{l}$ of a $2 \mathrm{mM}$ Fluo3/AM (Calbiochem, Bad Soden, Germany) for $15 \mathrm{~min}$ at $37^{\circ} \mathrm{C}$ [21]. Thereafter, $2 \mu$ of Fluo3/AM were added for additional 25 $\mathrm{min}$. To obtain a positive control, labeled erythrocytes were exposed to $1.0 \mu \mathrm{M}$ ionomycin for $10 \mathrm{~min}$ [21]. $\mathrm{Ca}^{2+}$-dependent fluorescence intensity was measured by FACS Calibur.

Determination of reactive oxygen species (ROS)

Percoll-separated erythrocytes $\left(2 \times 10^{7} / \mathrm{ml}\right)$ were incubated with $0.4 \mathrm{mM} \mathrm{2} 2^{\prime}, 7^{\prime}$-dichlorofluorescein diacetate (DCF; Sigma-Aldrich, Germany) for $15 \mathrm{~min}$ at $37^{\circ} \mathrm{C}$ according to Amer et al. [22]. For a positive control, wt erythrocytes were exposed to $2 \mathrm{mM} \mathrm{H}_{2} \mathrm{O}_{2}$ for 10 min before DCF-labelling. DCF-dependent intensity of fluorescence was measured by FACS Calibur.

Enzyme assay

The activity of enzymes involved in anaerobic glycolysis, oxidative-defense and nucleotide metabolism was determined according to the methods recommended by the International Committee for Standardization in Haematology [23], with the use of leukocytes- and platelets-free erythrocyte lysates as we previously described $[24,25]$. The measurements were adopted for mouse samples. Briefly, the enzyme reaction was pre-incubated for $10 \mathrm{~min}$ at $37^{\circ} \mathrm{C}$, thereafter substrate and erythrocyte lysate were added. Absorbance was measured at $340 \mathrm{~nm}$ in $1 \mathrm{~min}$ intervals for $20 \mathrm{~min}$ at $37^{\circ} \mathrm{C}$ (spectrophotometer Infinite 200 Nanoquant) and specific enzyme activity was calculated using the Lambert-Beer law. All chemicals and purified enzymes were purchased from Sigma-Aldrich.

\section{Real-time PCR for hypoxia regulated genes}

Reticulocytes were separated from peripheral blood as previously described [26]. Total reticulocyte RNA was isolated using TRI Reagent (Sigma-Aldrich), reverse-transcribed using SuperScript ${ }^{\circledR}$ VILO ${ }^{\text {TM }}$ cDNA Synthesis Kit (Life Technologies, NY, USA) according to manufacturer's instructions and used for quantitative real-time Polymerase Chain Reaction (qPCR). Transcript levels of Foxo3A [27], Runx1, Tfrc and Hk1 [28] were measured by real-time PCR using gene specific Taqman probes: (Mm01185722_m1, Mm01213404 $\mathrm{m} 1, \mathrm{Mm} 00441941 \_\mathrm{m} 1$ and Mm00439344_m1, respectively). The data were normalized to the expression of beta-actin (Actb; 4352341E) and to mRNA levels of wt reticulocytes. The statistical significance of relative expression changes in target mRNA levels was analyzed using the REST @ 2009 software [29].

\section{Measurement of ATP/ADP}

ATP and ADP were assayed by reverse phase HPLC-MS/MS with ionization atmospheric pressure (HPLC Dionex Ultimate 3000 MS, Thermo Scientific, USA; LC/MS/MS System MDS API 3200, Applied Biosystems, USA) in freshly prepared erythrocyte lysates extracted with 5\% trichloracetic acid (Sigma-Aldrich).

\section{Statistical analyses}

The Student's t-test was used to determine the statistical significance of the results. $P$ values were calculated using the Origin 6.1 software (OriginLab Corporation, Norhampton, MA, USA). $P$ values less than 0.05 were considered to be statistically significant.

\section{Results}

Accelerated clearance of DMT1-mutant erythrocytes in vivo

Homozygous DMT1-mutant $(\mathrm{mk} / \mathrm{mk})$ mice exhibit severe hypochromic microcytic anemia (mean corpuscular volume, MCV $37.2 \pm 1.8 \mathrm{fl} v s .54 .3 \pm 0.8 \mathrm{fl}$ in wt mice), reticulocytosis and splenomegaly [14]. We first focused on the in vivo erythrocyte survival. Erythrocytes 
Fig. 1. Clearance of normal and DMT1-mutant erythrocytes from circulating blood. The percentage of CFSE-labeled DMT1-mutant erythrocytes is lower when compared to wt erythrocytes at indicated time-points post injection. Values are given as \% of CFSE-labeled erythrocytes determined two hours after the injection into the wt mice (means \pm SDs, $n$ $=4$ each). Some SDs are smaller than the respective symbol. h: hours, d: days, ${ }^{*} \mathrm{P}<0.01,{ }^{*} \mathrm{P}<0.05$.

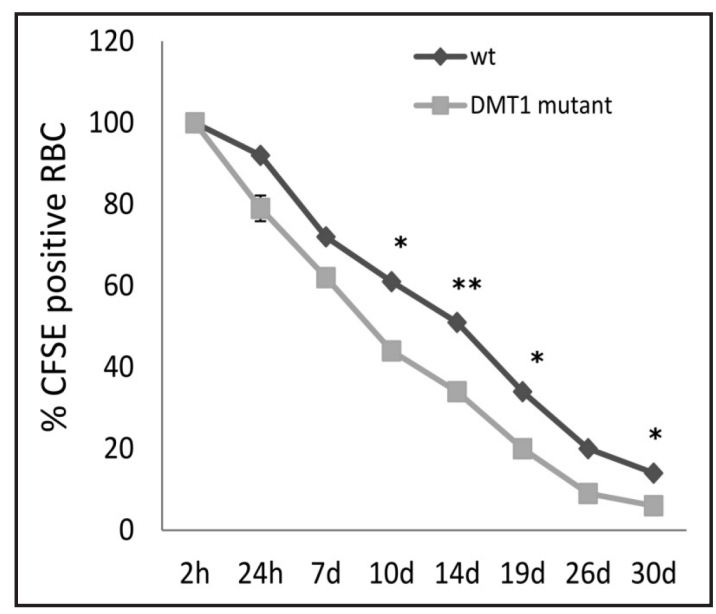

Table 1. Determination of hemolysis and bilirubin levels (values indicate means \pm SDs, $n=3$ 5 for wt mice, $\mathrm{n}=3-9$ for DMT1-mutant mice)

\begin{tabular}{lccc}
\hline & $\begin{array}{c}\text { Hemolysis in vitro } \\
{[\%]}\end{array}$ & $\begin{array}{c}\text { Cryohemolysis } \\
{[\%]}\end{array}$ & $\begin{array}{c}\text { Bilirubin } \\
{[\mu \mathrm{M}]}\end{array}$ \\
\hline wt & $9.9 \pm 0.5$ & $21.8 \pm 3.9$ & $9.2 \pm 4.8$ \\
DMT1-mutant & $10.5 \pm 1.4$ & $17.6 \pm 3.8$ & $9.0 \pm 3.6$ \\
\hline
\end{tabular}

from DMT1-mutant mice and wt controls were in vitro labeled with CFSE fluorescent dye and injected into the wt mice. Blood was taken from injected mice, and percentage of circulating CFSE-positive erythrocytes was calculated in the respective time periods. The labeling of wt and DMT1-mutant erythrocytes was comparable, as determined by CFSE fluorescence at 2 hours after the injection (not shown). As shown in Fig. 1, we observed an accelerated clearance of CFSE-labeled DMT1-mutant erythrocytes from circulation when compared to wt erythrocytes; the difference in the percentage of CFSE-positive erythrocytes was significant at day $10(\mathrm{P}=0.016), 14(\mathrm{P}=0.006), 19(\mathrm{P}=0.011)$ and $30(\mathrm{P}=0.038)$. This result indicates faster removal of DMT1-mutant erythrocytes from circulating blood in vivo.

Exclusion of the erythrocyte membrane integrity defect

We next assessed the membrane integrity by the in vitro hemolysis assays. In the first test the hemolysis was determined after 24 hour incubation of erythrocytes in isotonic Ringer solution at $37^{\circ} \mathrm{C}$. The percentage of hemolysis was $9.9 \pm 0.5$ for wt erythrocytes and 10.5 \pm 1.4 for DMT1-mutant erythrocytes (Table 1). Neither the second test, the cryohemolysis test, revealed any differences between the DMT1-mutant mice and their wt littermates; the hemolysis was $17.6 \pm 3.8 \%$ and $21.8 \pm 3.9 \%$ respectively (Table 1 ). In agreement, also the plasma bilirubin levels were comparable (wt mice: $9.2 \pm 4.8 \mu \mathrm{M}$; DMT1-mutant mice: $9.0 \pm 3.6$ $\mu \mathrm{M}$ ) (Table 1). These analyses excluded hemolysis as the cause of shortened lifespan of erythrocytes.

\section{Increased destruction of DMT1-mutant erythrocytes in stress conditions}

To evaluate possible involvement of eryptosis in the accelerated clearance of DMT1mutant erythrocytes, we assessed the phosphatidylserine exposure on erythrocyte membrane. Erythrocytes were maintained in vitro in Ringer solution and Annexin V binding to exposed phosphatidylserines was determined using FACS. Under physiological conditions (5 hours in isotonic Ringer solution), DMT1-mutant erythrocytes showed significantly enhanced Annexin V binding when compared to wt erythrocytes $(3.1 \pm 0.9 \%$ vs. $10.0 \pm 6.1 \%$, $\mathrm{P}=0.021, \mathrm{n}=6$ each). A short exposure of erythrocytes to hyperosmotic shock $(700 \mathrm{mM}$ Ringer) increased the percentage of Annexin V-positive cells for DMT1-mutant mice (to $25.4 \pm 7.6 \%$ at 5 hours and to $43.5 \pm 10.8 \%$ at 7 hours) while the proportion of Annexin V-positive wt erythrocytes remained almost unchanged (Fig. 2A). More dramatic effect on phosphatidylserine exposure was obtained under glucose-depleted conditions, where 
Fig. 2. Annexin $\mathrm{V}$ binding after exposure to stress conditions in vitro. DMT1-mutant erythrocytes showed increased Annexin V binding after 5 and 7 hour (h) exposure to hyperosmotic shock (Panel A) and glucose depletion (Panel B) in vitro when compared to wt erythrocytes. Original histograms of representative measurements are also shown (right). Values are given as mean \pm SDs $\left(\mathrm{n}=4\right.$, each). ${ }^{* * *} \mathrm{P}<0.001$, $* * \mathrm{P}<0.01$.

Fig. 3. Intracellular $\mathrm{Ca}^{2+}$ content. The intensity of fluorescence, which reflects the intracellular $\mathrm{Ca}^{2+}$ concentration, is higher in DMT1-mutant erythrocytes when compared to wt erythrocytes. Ionomycin treated erythrocytes served as positive controls for increased $\mathrm{Ca}^{2+}$ content. Representative histograms of $\mathrm{Ca}^{2+}$-dependent fluorescence are also shown (bottom). Values are given as mean \pm SDs $(\mathrm{n}=3-5) .{ }^{* * *} \mathrm{P}<0.001$, ${ }^{* *} \mathrm{P}<0.01,{ }^{*} \mathrm{P}<0.05$.

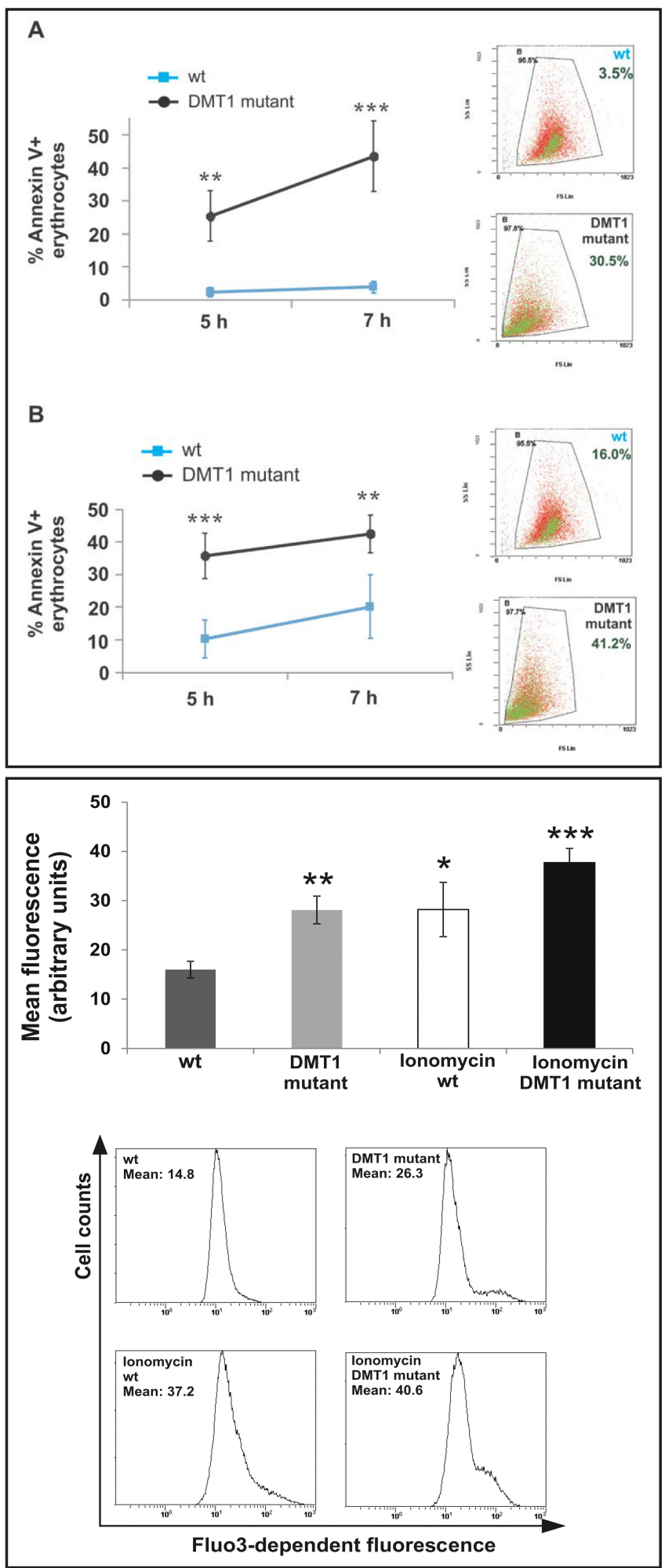

significant increase in Annexin V positivity was observed for both wt (10.2 $\pm 5.7 \%$ ) and DMT1mutant $(35.8 \pm 6.9 \%)$ erythrocytes and the proportion further increased with prolonged incubation (Fig. 2B). These results confirmed increased phosphatidylserine exposure on the membrane of DMT1-mutant erythrocytes and their enhanced susceptibility to stress. As cell shrinkage is another characteristic feature of eryptosis, reduction in cell volume (detected by lower forward scatter, FS) has become obvious after 7 hour incubation under 
Fig. 4. Determination of reactive oxygen species (ROS). DMT1-mutant erythrocytes have increased intracellular ROS content when compared to wt erythrocytes as determined by increased intensity of DCF-dependent fluorescence. Wt erythrocytes exposed to 2 mM $\mathrm{H}_{2} \mathrm{O}_{2}$ served as a positive control for high ROS levels. Representative histograms of DCF-dependent fluorescence are also shown (bottom). Values are given as mean \pm SDs ( $n=3$, each). ${ }^{* * *} \mathrm{P}<0.001,{ }^{*} \mathrm{P}<0.05$.

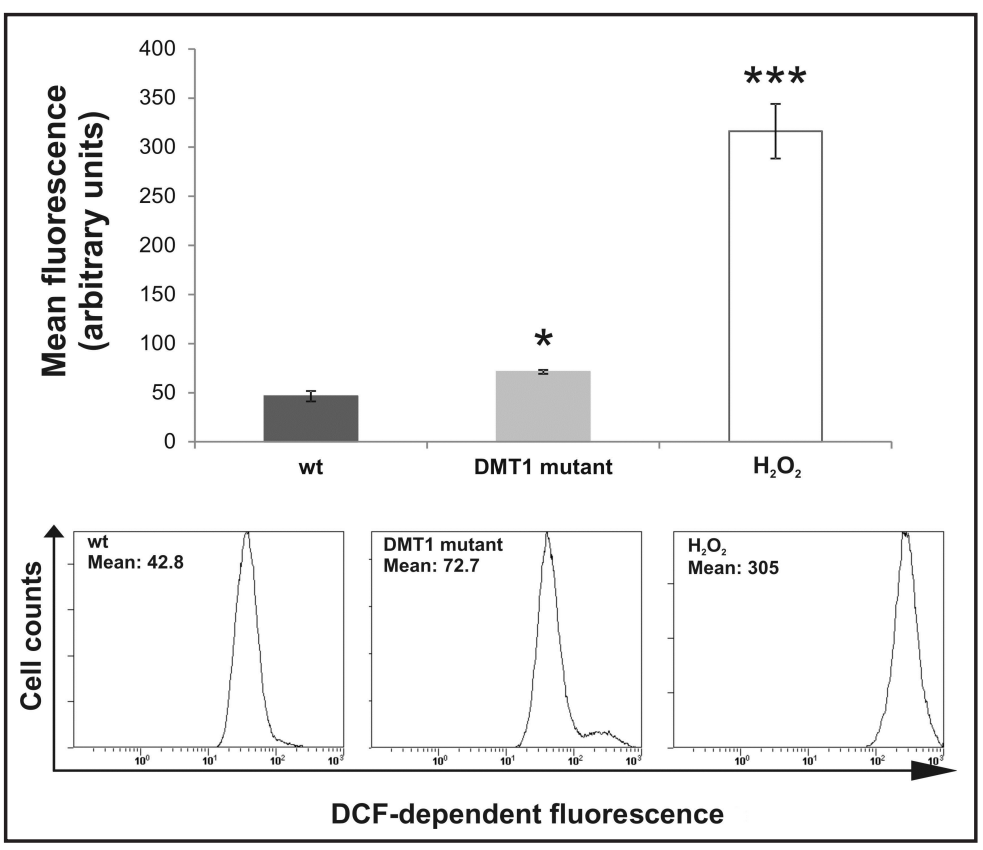

both stress conditions when compared to isotonic Ringer solution. The mean FS value of wt erythrocytes has reduced from $422 \pm 13$ to $353 \pm 11$ for hyperosmotic shock and to $404 \pm 3$ for glucose depletion; mean FS value of DMT1-mutant erythrocytes has reduced from $235 \pm 6$ to $216 \pm 3$ for hyperosmotic shock and to $218 \pm 10$ for glucose depletion.

Elevated levels of cytosolic $\mathrm{Ca}^{2+}$ in DMT1-mutant erythrocytes

Previous study suggested that G185R mutation in DMT1 leads to a gain of constitutive $\mathrm{Ca}^{2+}$ permeability [30]. As it is known that eryptosis is triggered by cytosolic $\mathrm{Ca}^{2+}$ activity [11] we assessed the concentration of $\mathrm{Ca}^{2+}$ within erythrocytes. For this purpose, erythrocytes were loaded with $\mathrm{Ca}^{2+}$-sensitive fluorescence dye Fluo3/AM and the intensity of fluorescence was measured by FACS [21]. Ionomycin-treated wt erythrocytes were used as positive controls. As it is shown in Fig. 3, the mean intensity of fluorescence was significantly higher for DMT1mutant erythrocytes $(28.1 \pm 2.8)$ when compared to wt erythrocytes $(16.0 \pm 1.7)$ confirming higher content of intracellular $\mathrm{Ca}^{2+}$ in DMT1-mutant erythrocytes.

DMT1-mutant erythrocytes have increased ROS and hyperactivated anti-oxidative defense

Next we tested whether the observed increased destruction of DMT1-mutant erythrocytes was associated with ROS accumulation. Both wt and DMT1-mutant erythrocytes were in vitro incubated with DCF fluorescence dye, thereafter DCF-dependent intensity of fluorescence, which is proportional to the concentration of ROS, was determined on FACS. The measurements revealed higher ROS levels in DMT1-mutant erythrocytes when compared to the erythrocytes of wt littermates (Fig. 4). Erythrocytes of wt mice exposed to $\mathrm{H}_{2} \mathrm{O}_{2}$ served as a positive control [22].

Then we assessed whether and how increased ROS influence the anti-oxidative defense of DMT1-mutant erythrocytes. The activity of antioxidant enzymes was measured in erythrocyte lysate free of leukocytes and platelets according to recommended methods [23], as we previously described [24]. DMT1-mutant erythrocytes showed significantly higher activity of the following enzymes: glutathione peroxidase ( $\mathrm{GPx}, 1.6$-times, $\mathrm{P}=0.023$ ), catalase (CAT, 1.9-times, $\mathrm{P}=0.018$ ) and methemoglobin reductase (MtHbR, 1.9-times, $\mathrm{P}=0.00002$ ) (Fig. $5 \mathrm{~A})$ than wt controls. In agreement, we also detected 2.4-times higher activity of glutathione reductase (GR) (Fig. 5A) and 1.8-higher activity of glucose-6-phosphate dehydrogenase (G6PD) (Fig. 5B) in DMT1-mutant erythrocytes than in wt erythrocytes, suggesting elevated levels of the oxidized form of glutathione (GSSG) that needs to be catalyzed to its reduced form (GSH). In addition, the expression levels of Foxo3A, a transcription factor responsible for 
Fig. 5. Assessment of anti-oxidative defense and hypoxia regulated genes. A-B) The activity of antioxidant enzymes is higher in DMT1-mutant erythrocytes than in wt erythrocytes; glutathione peroxidase (GPx), catalase (CAT), methemoglobin reductase (MtHbR), glutathione reductase (GR) (Panel A) and glucose6-phosphate dehydrogenase (G6PD) (Panel B). Enzyme activity is expressed in $\mathrm{IU} / \mathrm{g}$ hemoglobin (Hb). C) Real-time PCR analysis revealed increased expression of Foxo3A, Runx1, Tfrc and Hk1 in DMT1-mutant reticulocytes when compared to wt reticulocytes. The data were normalized to the expression of beta-actin and to mRNA levels of wt reticulocytes (black bars). Values indicate means \pm SDs, $n=3-7$ for wt mice, $\mathrm{n}=3$ for DMT1-mutant mice; *** $\mathrm{P}<0.001,{ }^{* *} \mathrm{P}<0.01$, ${ }^{*} \mathrm{P}<0.05, N S-$ not significant.
A
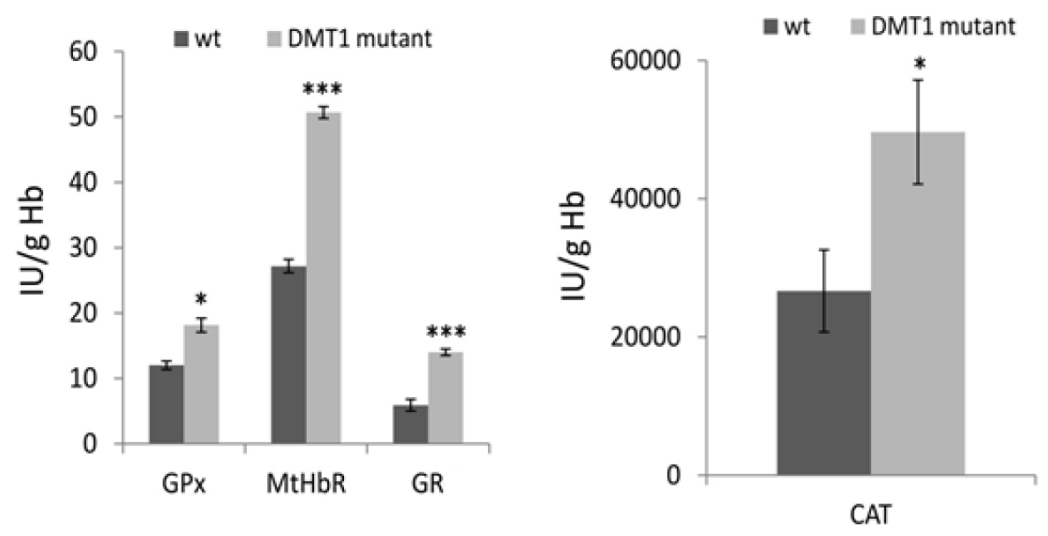

B

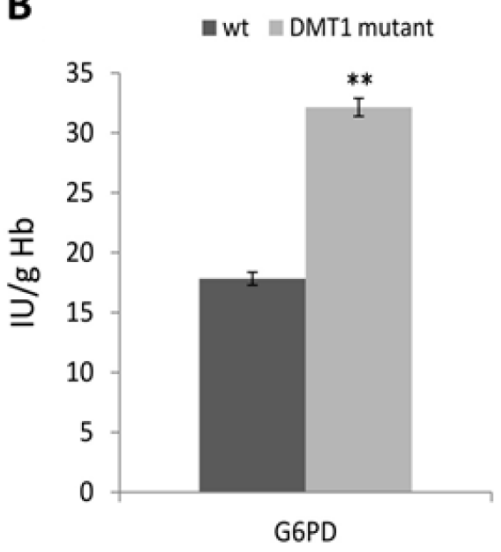

C

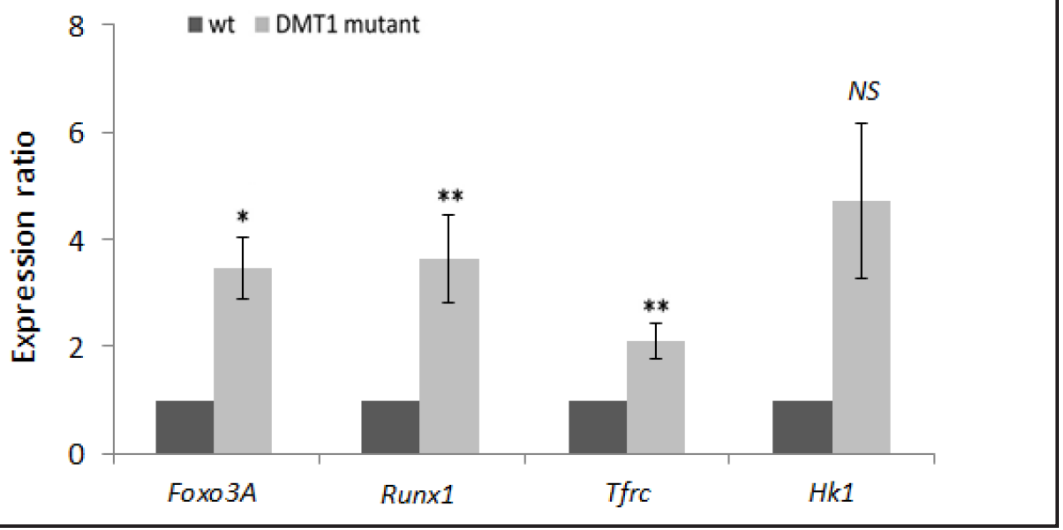

the upregulation of the anti-oxidative defense enzymes [27], were found to be significantly elevated in DMT1-mutant reticulocytes when compared to the wt controls, along with other selected markers of augmented hypoxia sensing (Fig. 5C) [28]. These data suggest that ROS exaggerate anti-oxidative defense in DMT1-mutant erythrocytes but the buffering capacity of this defense is insufficient to eliminate ROS effectively. In addition, the results also indicate that tissue hypoxia may limit the extent of anti-oxidative capacity in DMT1-mutant red blood cells.

Increased need for ATP in DMT1-mutant erythrocytes

Another essential metabolic pathway in erythrocytes is anaerobic glycolysis responsible for the production of ATP [31]. The enzyme assays of selected enzymes of this pathway 


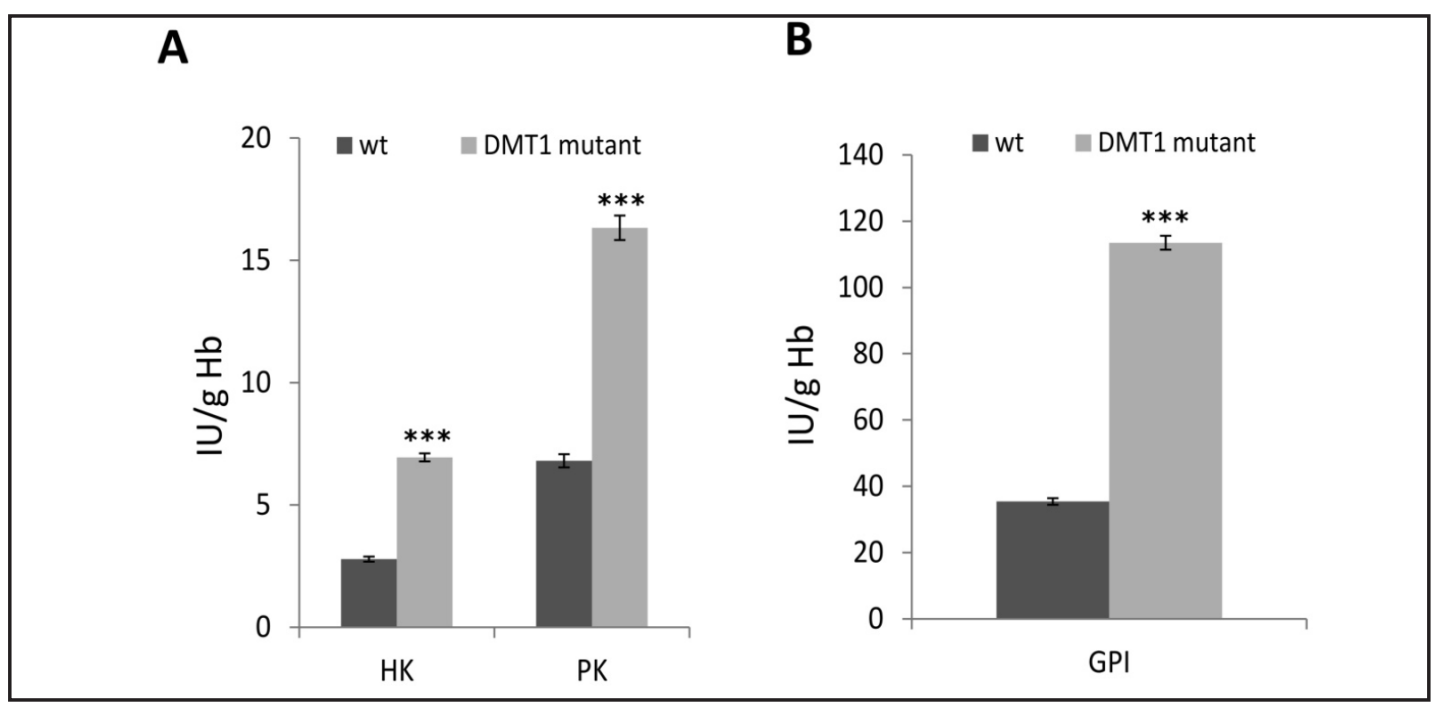

Fig. 6. Analysis of anaerobic glycolysis in erythrocytes. DMT1-mutant erythrocytes showed accelerated anaerobic glycolysis when compared to wt erythrocytes as documented by increased activity of the following enzymes involved in Embden-Meyerhof pathway: hexokinase (HK), pyruvate kinase (PK) (Panel A) and glucose-phosphate isomerase (GPI) (Panel B). Enzyme activity is expressed in IU/g hemoglobin (Hb). Values indicate means \pm SDs, $n=5-7$ for wt mice, $n=3$ for DMT1-mutant mice; ${ }^{* * *} \mathrm{P}<0.001$.

Table 2. Concentration of metabolites (values indicate means \pm SDs, $\mathrm{n}=14$ for wt mice, $\mathrm{n}=13$ for DMT1 mutant mice; ${ }^{* * *} \mathrm{P}<0.001$ )

\begin{tabular}{lccc}
\hline & ATP $[\mu \mathrm{mol} / \mathrm{l}]$ & $\mathrm{ADP}[\mu \mathrm{mol} / \mathrm{l}]$ & $\mathrm{ATP} / \mathrm{ADP}$ \\
\hline wt & $2.04 \pm 0.52$ & $0.72 \pm 0.20$ & $2.83 \pm 0.56$ \\
DMT1-mutant & $1.76 \pm 0.60$ & $1.03 \pm 0.37$ & $1.70 \pm 0.49 * * *$ \\
\hline
\end{tabular}

revealed that in comparison with wt erythrocytes the DMT1-mutant erythrocytes have increased activities of hexokinase (HK, 2.5-times), pyruvate kinase (PK, 2.4-times) (Fig. 6A) and glucose-phosphate isomerase (GPI, 3.2-times) (Fig. 6B). Using HPLC-MS/MS we subsequently determined the concentration of ATP and ADP and calculated the ATP/ADP ratio - an indicator of cellular energy status. As shown in Table 2, DMT1-mutant erythrocytes had elevated levels of ADP and reduced levels of ATP and consequently reduced the ATP/ ADP ratio than wt controls. This result is in agreement with accelerated anaerobic glycolysis and suggests increased need for ATP in DMT1-mutant erythrocytes.

\section{Discussion}

DMT1 deficiency leads to severe repression of numerous processes in developing erythroid cells, namely to defective differentiation, reduced survival of erythroid progenitors and increased apoptosis of erythroblasts [14]. On the level of reticulocytes, DMT1 deficiency leads to reduced rate of heme synthesis [32]. Our earlier data also revealed block of terminal hemoglobinization in the DMT1-mutant burst forming unit-erythroid (BFU-E) colonies that was associated with the activation of heme-regulated inhibitor (HRI) kinase, which specifically phosphorylates the alpha subunit of the eukaryotic initiation factor 2 (eIF2 $\alpha$ ) and attenuates globin translation [33]. Therefore, it was reasonable to address a possible detrimental effect of DMT1 deficiency on life span and metabolism of mature erythrocytes, the last stage of DMT1-mutant erythroid differentiation that has not been analyzed yet. 
A specific role of iron deficiency in the programmed cell death of erythrocytes (eryptosis) has been proposed in an earlier study [9]. Eryptosis is initiated by an increase in red cell cytosolic calcium; iron-depleted erythrocytes, when exposed to stress conditions, were reported to activate $\mathrm{Ca}^{2+}$-permeable cation channel allowing $\mathrm{Ca}^{2+}$ entry $[9,11,12]$. Increased concentration of $\mathrm{Ca}^{2+}$ within erythrocytes was shown to stimulate $\mathrm{Ca}^{2+}$-sensitive cell membrane scrambling with subsequent phosphatidylserine exposure, leading to removal of such erythrocytes from circulation [11, 12, 34]. Indeed, our experiments revealed markers of eryptosis and accelerated clearance of DMT1-mutant erythrocytes from circulating blood. However, it is important to note, that studies by Xu et al. [30] predicted that increased $\mathrm{Ca}^{2+}$ entry into DMT1-mutant cells is an intrinsic feature of the G185R mutation. Although we cannot estimate the contribution of G185R mutation and the iron-depleted erythroid environment per se, we observed significantly elevated levels of cytosolic $\mathrm{Ca}^{2+}$ in DMT1-mutant erythrocytes as a possible cause of events resulting in suicidal cell death of DMT1-mutant red blood cells. The possible involvement of a membrane defect in the in vivo accelerated clearance of erythrocytes was excluded by normal results of tests used to determine hemolysis and by unaltered bilirubin levels when compared to wt mice.

Iron deficiency of erythroid cells in DMT1-mutant mice, along with increase in cytosolic $\mathrm{Ca}^{2+}$ and membrane damage are all consistent with augmented state of cellular oxidative stress [35]. Therefore, we hypothesize that oxidative stress contributes to shortened life span of DMT1-deficient erythrocytes. Our data revealed increased ROS and hyperactivated anti-oxidative defense in DMT1-mutant red blood cells, which, however, was insufficient to fully buffer elevated toxic radicals. It seems likely that the contributing factor, causing ROS generation that exceeds anti-oxidant capacity of the DMT1-mutant erythrocyte defense system, is tissue hypoxia.

In DMT1-mutant mice, anemia causes decreased tissue oxygenation, which in turn leads to increased HIF activity as demonstrated by increased expression of HIF-targets (hypoxia signature genes) in the DMT1-mutant reticulocytes. In hypoxia, ROS production in erythrocytes often exceeds anti-oxidant system's buffering ability, creating hypoxia-induced oxidative stress of red blood cells [36]. Thus, we propose that hypoxia limits the antioxidative capacity of DMT1-mutant erythrocytes and renders them vulnerable to oxidative injury caused primarily by iron deficiency.

Eryptosis is associated with decreased cytosolic ATP concentration [37]. Oxidative injury of red blood cells, together with deformation of erythrocyte membrane, leads to ATP release from erythrocytes [38]. These events likely contributed to reduced ATP/ADP ratio in our DMT1-mutant erythrocytes. As a consequence, selected enzymes of the EmbdenMeyerhof glycolytic pathway were found to be upregulated, consistently with higher demand for ATP in DMT1-mutant erythrocytes.

In conclusion our study revealed that DMT1-deficiency negatively affects erythrocyte metabolism and reduces their capacity to cope with stress. Increased content of cytosolic calcium, insufficient anti-oxidative defense and reduced levels of ATP shorten the life span of mature DMT1-mutant erythrocytes. We propose that this erythrocyte defect is a contributing factor in the pathophysiology of anemia caused by DMT1 mutations.

\section{Disclosure Statement}

The authors declare no conflicts of interest.

\section{Acknowledgments}

The study was supported by Czech Grant Agency (grant No. P305/11/1745), Education for Competitiveness Operational Program (CZ.1.07/2.3.00/20.0164) and by Internal Grant of Palacky University Olomouc (LF_2014_011). 


\section{References}

1 Gunshin H, Fujiwara Y, Custodio AO, Direnzo C, Robine S, Andrews NC: Slc11a2 is required for intestinal iron absorption and erythropoiesis but dispensable in placenta and liver. J Clin Invest 2005;115:12581266.

2 Mims MP, Guan Y, Pospisilova D, Priwitzerova M, Indrak K, Ponka P, Divoky V, Prchal JT: Identification of a human mutation of DMT1 in a patient with microcytic anemia and iron overload. Blood 2005;105:13371342.

- I Iolascon A, d'Apolito M, Servedio V, Cimmino F, Piga A, Camaschella C: Microcytic anemia and hepatic iron overload in a child with compound heterozygous mutations in DMT1 (SCL11A2). Blood 2006;107:349-354.

4 Beaumont C, Delaunay J, Hetet G, Grandchamp B, de Montalembert M, Tchernia G: Two new human DMT1 gene mutations in a patient with microcytic anemia, low ferritinemia, and liver iron overload. Blood 2006;107:4168-4170.

5 Blanco E, Kannengiesser C, Grandchamp B, Tasso M, Beaumont C: Not all DMT1 mutations lead to iron overload. Blood Cells Mol Dis 2009;43:199-201.

-6 Bardou-Jacquet E, Island ML, Jouanolle AM, Détivaud L, Fatih N, Ropert M, Brissot E, Mosser A, Maisonneuve H, Brissot P, Loréal O: A novel N491S mutation in the human SLC11A2 gene impairs protein trafficking and in association with the G212V mutation leads to microcytic anemia and liver iron overload. Blood Cells Mol Dis 2011;47:243-248.

7 Fleming MD, Trenor CC 3rd, Su MA, Foernzler D, Beier DR, Dietrich WF, Andrews NC: Microcytic anaemia mice have a mutation in Nramp2, a candidate iron transporter gene. Nat Genet 1997;16:383-386.

8 Fleming MD, Romano MA, Su MA, Garrick LM, Garrick MD, Andrews NC: Nramp2 is mutated in the anemic Belgrade (b) rat: evidence of a role for Nramp2 in endosomal iron transport. Proc Natl Acad Sci U S A 1998;95:1148-1153.

-9 Kempe DS, Lang PA, Duranton C, Akel A, Lang KS, Huber SM, Wieder T, Lang F: Enhanced programmed cell death of iron-deficient erythrocytes. FASEB J 2006;20:368-370.

10 Lang KS, Roll B, Myssina S, Schittenhelm M, Scheel-Walter HG, Kanz L, Fritz J, Lang F, Huber SM, Wieder T: Enhanced erythrocyte apoptosis in sickle cell anemia, thalassemia and glucose-6-phosphate dehydrogenase deficiency. Cell Physiol Biochem 2002;12:365-372.

11 Lang KS, Lang PA, Bauer C, Duranton C, Wieder T, Huber SM, Lang F: Mechanisms of suicidal erythrocyte death. Cell Physiol Biochem 2005;15:195-202.

12 Lang KS, Duranton C, Poehlmann H, Myssina S, Bauer C, Lang F, Wieder T, Huber SM: Cation channels trigger apoptotic death of erythrocytes. Cell Death Differ 2003;10:249-256.

13 Duranton C, Huber SM, Lang F: Oxidation induces a Cl(-)-dependent cation conductance in human red blood cells. J Physiol 2002;539:847-855.

14 Horvathova M, Kapralova K, Zidova Z, Dolezal D, Pospisilova D, Divoky V: Erythropoietin-driven signaling ameliorates the survival defect of DMT1-mutant erythroid progenitors and erythroblasts. Haematologica 2012;97:1480-1488.

15 Goodman SR, Hughes KM, Kakhniashvili DG, Neelam S: The isolation of reticulocyte-free human red blood cells. Exp Biol Med (Maywood) 2007;232:1470-1476.

-16 Qadri SM, Mahmud H, Lang E, Gu S, Bobbala D, Zelenak C, Jilani K, Siegfried A, Föller M, Lang F: Enhanced suicidal erythrocyte death in mice carrying a loss-of-function mutation of the adenomatous polyposis coli gene. J Cell Mol Med 2012;16:1085-1093.

17 Akel A, Wagner CA, Kovacikova J, Kasinathan RS, Kiedaisch V, Koka S, Alper SL, Bernhardt I, Wieder T, Huber SM, Lang F: Enhanced suicidal death of erythrocytes from gene-targeted mice lacking the Cl-/HCO(3)(-) exchanger AE1. Am J Physiol Cell Physiol 2007;292:C1759-C1767.

18 Ghashghaeinia M, Toulany M, Saki M, Bobbala D, Fehrenbacher B, Rupec R, Rodemann HP, Ghoreschi K, Röcken M, Schaller M, Lang F, Wieder T: The NFkB pathway inhibitors Bay 11-7082 and parthenolide induce programmed cell death in anucleated Erythrocytes. Cell Physiol Biochem 2011;27:45-54.

19 Streichman S, Gescheidt Y: Cryohemolysis for the detection of hereditary spherocytosis: correlation studies with osmotic fragility and autohemolysis. Am J Hematol 1998;58:206-212.

20 Cruickshank AM: ACP Best Practise No 166: CSF spectrophotometry in the diagnosis of subarachnoid haemorrhage. J Clin Pathol 2001;54:827- 830. 
21 Kempe DS, Akel A, Lang PA, Hermle T, Biswas R, Muresanu J, Friedrich B, Dreischer P, Wolz C, Schumacher U, Peschel A, Götz F, Döring G, Wieder T, Gulbins E, Lang F: Suicidal erythrocyte death in sepsis. J Mol Med (Berl) 2007;85:273-281.

22 Amer J, Dana M, Fibach E: The antioxidant effect of erythropoietin on thalassemic blood cells. Anemia 2010;2010:978710.

-23 Beutler E, Blume KG, Kaplan JC, Löhr GW, Ramot B, Valentine WN: International Committee for Standardization in Haematology: recommended methods for red-cell enzyme analysis. Br J Haematol 1977;35:331-340.

24 Mojzikova R, Dolezel P, Pavlicek J, Mlejnek P, Pospisilova D, Divoky V: Partial glutathione reductase deficiency as a cause of diverse clinical manifestations in a family with unstable hemoglobin (Hemoglobin Haná, $\beta 63(E 7)$ His-Asn). Blood Cells Mol Dis 2010;45:219-222.

25 Mojzikova R, Koralkova P, Holub D, Zidova Z, Pospisilova D, Cermak J, Striezencova Laluhova Z, Indrak K, Sukova M, Partschova M, Kucerova J, Horvathova M, Divoky V: Iron status in patients with pyruvate kinase deficiency: neonatal hyperferritinaemia associated with a novel frameshift deletion in the PKLR gene (p.Arg518fs), and low hepcidin to ferritin ratios. Br J Haematol 2014;165:556-563.

26 Arnstein HR, Cox RA, Hunt JA: The function of high-molecular-weight ribonucleic acid from rabbit reticulocytes in haemoglobin biosynthesis. Biochem J 1964;92:648-661.

27 Bakker WJ, Harris IS, Mak TW: FOXO3a is activated in response to hypoxic stress and inhibits HIF1-induced apoptosis via regulation of CITED2. Mol Cell 2007;28:941-953.

28 Kapralova K, Lanikova L, Lorenzo F, Song J, Horvathova M, Divoky V, Prchal JT: RUNX1 and NF-E2 upregulation is not specific for MPNs, but is seen in polycythemic disorders with augmented HIF signaling. Blood 2014;123:391-394.

-29 Pfaffl MW, Horgan GW, Dempfle L: Relative expression software tool (REST) for group-wise comparison and statistical analysis of relative expression results in real-time PCR. Nucleic Acids Res 2002;30:E36.

- $30 \mathrm{Xu} \mathrm{H,} \mathrm{Jin} \mathrm{J,} \mathrm{DeFelice} \mathrm{LJ,} \mathrm{Andrews} \mathrm{NC,} \mathrm{Clapham} \mathrm{DE:} \mathrm{A} \mathrm{spontaneous,} \mathrm{recurrent} \mathrm{mutation} \mathrm{in} \mathrm{divalent} \mathrm{metal}$ transporter-1 exposes a calcium entry pathway. PLoS Biol 2004;2:E50.

-31 van Wijk R, van Solinge WW: The energy-less red blood cell is lost: erythrocyte enzyme abnormalities of glycolysis. Blood 2005;106:4034-4042.

-32 Canonne-Hergaux F, Zhang AS, Ponka P, Gros P: Characterization of the iron transporter DMT1 (NRAMP2/ DCT1) in red blood cells of normal and anemic mk/mk mice. Blood 2001;98:3823-3830.

33 Priwitzerova M, Pospisilova D, Indrak K, Ponka P, Divoky V: Consequences of DMT1 mutation on proliferation and hemoglobinization of erythroid progenitors in vitro. Blood (ASH Annual Meeting Abstracts) 2004;104: Abstract 3190.

34 Lang F, Lang E, Föller M: Physiology and pathophysiology of eryptosis. Transfus Med Hemother 2012;39:308-314.

-35 Nagababu E, Gulyani S, Earley CJ, Cutler RG, Mattson MP, Rifkind JM: Iron-Deficiency Anemia Enhances Red Blood Cell Oxidative Stress. Free Radic Res 2008; 42:824-829.

- 36 Rogers SC, Said A, Corcuera D, McLaughlin D, Kell P, Doctor A: Hypoxia limits antioxidant capacity in red blood cells by altering glycolytic pathway dominance. FASEB J 2009;23:3159-3170.

- 37 Lang F, Qadri SM: Mechanisms and significance of eryptosis, the suicidal death of erythrocytes. Blood Purif 2012;33:125-130.

-38 Sprague RS, Stephenson AH, Ellsworth ML: Red not dead: signaling in and from erythrocytes. Trends Endocrinol Metab 2007;18:350-355. 